\title{
配向処理・高密度化による $\mathrm{CuAlO}_{2}$ 熱西材料の劍製と高性能化
}

\author{
魯 云 $^{* 1}$, 神島 弾 ${ }^{* 2}$, 相楽 勝裕 ${ }^{* 2}$, 野末 貴裕 ${ }^{* 2}$, 吉田 浩之 ${ }^{* 3}$, 浅沼 博 ${ }^{* 1}$
}

\section{Fabrication and performance improvement of $\mathrm{CuAlO}_{2}$ thermoelectrics by orientation process and densification}

\author{
Yun LU* ${ }^{* 1}$, Dan KAMIJIMA, Katsuhiro SAGARA, \\ Takahiro NOZUE, Hiroyuki YOSHIDA and Hiroshi ASANUMA \\ ${ }^{* 1}$ Graduate School \& Faculty of Engineering, Chiba University \\ 1-33 Yayoi-cho Inage-ku Chiba-shi Chiba 263-8522 Japan
}

Thermoelectric materials can convert the unused thermal energy into the electrical energy. Therefore, thermoelectric materials are expected as a technology to enable efficient use of waste heat. However, thermoelectric materials have several challenges such as using the rare or poisonous elements, and working only at low temperatures. Thus, developments of new thermoelectric materials such as metal oxides are paid much attention. From the above background, $\mathrm{CuAlO}_{2}$ thermoelectric material was fabricated and the properties have been improved in the previous works. Also, improvement of thermoelectric properties including the decrease of the electrical resistivity is necessary to practical use for thermoelectric oxide materials.

In this work, focus on $\mathrm{CuAlO}_{2}$ with a stratified crystallographic structure has a high anisotropy of electric resistivity. Therefore, we purpose for making the oriented $\mathrm{CuAlO}_{2}$ thermoelectric material in a control crystallographic orientation to decrease the electrical resistivity and to improve the thermoelectric performance. The multi-press forming process and reactive templated grain growth (RTGG) method were performed for fabricating green compact and sintered compact with orientation. $\mathrm{Al}_{2} \mathrm{O}_{3}$ powder with plate shape, $\mathrm{CuO}$ and $\mathrm{CuO}_{2}$ powders were used as the source materials.

Key Words : Thermoelectric Material, $\mathrm{CuAlO}_{2}$, Orientation, Multi-press Forming, Reactive Template Grain Growth Method, Spark Plasma Sintering

\section{1. 精 需}

熱電材料による熱電変換は, 廃熱として未利用のまま捨てられる熱エネルギーを電気エネルギーに変換し利用 できる技術であり, 再生可能エネルギーとして環境問題やエネルギー問題の改善に貢献できる. しかし, 現在実 用化されている熱電材料は, $\mathrm{Bi}, \mathrm{Te}, \mathrm{Sb}$ などの希少・有毒元素の使用や使用可能温度域の低さなどの課題があり， 高温域で使用可能で安価な金属酸化物の高性能熱電材料の開発が注目されている．その中，デラフォサイト $\mathrm{CuAlO}_{2}$ 層状酸化物は $\mathrm{p}$ 型の透明導電性薄膜としてその作製方法や特性評価などについて活発に研究開発がなされ ている(1)イ(3). また, $\mathrm{CuAlO}_{2}$ は熱電材料としての出力因子が高く, $6.62 \times 10^{-5} \mathrm{Wm}^{-1} \mathrm{~K}^{-2}$ に達すると報告(4)されており， 有望な熱電材料として期待されている(1),(5),(6). これまで著者らは $\mathrm{Cu}_{2} \mathrm{O}$ または $\mathrm{CuO}$ 粉末と $\mathrm{Al}_{2} \mathrm{O}_{3}$ 粉末を用いた $\mathrm{CuAlO}_{2}$ の生成における熱挙動, 化学反応, 反応生成物などを調查して基礎的なデータを報告(7),(8) した. $\mathrm{Cu}_{2} \mathrm{O}$ 粉末, または $\mathrm{CuO}$ 粉末と $\mathrm{Al}_{2} \mathrm{O}_{3}$ 粉末を出発原料として放電プラズマ焼結法, または通常の高温焼結法で $\mathrm{CuAlO}_{2}$ をそれぞ れ作製し，それらの熱電特性と比較検討している(8)ィ(10)．ところが，実用化にはさらなる高性能化が必要であり， 特に電気抵抗率の低減が課題となっている.

本研究では，層状結晶構造を有する $\mathrm{CuAlO}_{2}$ の電気抵抗率は結晶方位によって大きく異なる点 ${ }^{(5)}$ に着目し, 配向 性を有する $\mathrm{CuAlO}_{2}$ 焼結体を作製し，電気抵抗率を低減することで熱電変換性能を向上させることを目的とした.

\footnotetext{
${ }^{* 1}$ 正員, 千葉大学工学研究科（广263-8522 千葉市稲毛区弥生町 1-33）

*2 学生員, 千葉大学 大学院

E-mail: luyun@faculty.chiba-u.jp
} 


\section{2. 实殹方法}

\section{1 粉末の混合}

供試粉末に平均粒径 $10 \mu \mathrm{m}$, 純度 $98.8 \%$ の板状 $\mathrm{Al}_{2} \mathrm{O}_{3}$ 粉末，平均粒径 $3 \mu \mathrm{m}$, 純度 $90.0 \%$ の $\mathrm{CuO}$ 粉末，および平 均粒径 $3 \mu \mathrm{m}$, 純度 $99 \%$ の $\mathrm{Cu}_{2} \mathrm{O}$ 粉末を用いた. $\mathrm{CuAlO}_{2}$ に過不足なく反応するようにモル比 $\mathrm{Cu}: \mathrm{Al}=1: 1$ で秤量し, 混合した. 粉末の混合にはスターラーを用い, アセトンを加えた湿式にて回転速度 $100 \mathrm{rpm}$ で $1 \mathrm{~h}$ 混合し，その後 乾燥させてから乾式にて回転速度 300rpm で $3 \mathrm{~h}$ 混合を行った.

配向性を有する多結晶層状酸化物を作製する手法として, 反応性テンプレート粒成長法 ${ }^{(11),(12)}$ が知られている. 板状 $\mathrm{Al}_{2} \mathrm{O}_{3}$ 粉末を用いた理由は, 板状 $\mathrm{Al}_{2} \mathrm{O}_{3}$ の板面( $\left(\begin{array}{lll}0 & 0 & 10\end{array}\right)$ 方向を揃えて焼結することにより生成する $\mathrm{CuAlO}_{2}$ に配 向性を持たせるためである.

\section{2 多段プレス成形による配向処理}

金型に混合粉末を $2.0 \mathrm{~g}$ 充填し平らにならした後，万能材料試験機(REH-200-(株)島津製作所)によって圧力 230 , 345 , および $460 \mathrm{MPa}$ を印加した. これを 10 回繰り返して長さ $70 \mathrm{~mm}$, 幅 $30 \mathrm{~mm}$, 厚さ $2 \mathrm{~mm}$, 重さ $20 \mathrm{~g}$ の圧粉体 (Green Compact)を作製した。 これを，以下 GC-230，GC-345，GC-460 と略記する. 配向度を算出するための無配 向(Not-oriented)サンプルとして, 平均粒径 $1 \mu \mathrm{m}$, 純度 $99.98 \%$ の粒状 $\mathrm{Al}_{2} \mathrm{O}_{3}$ 粉末と $\mathrm{CuO}$ 粉末の混合粉末を同じ圧力 を印加し，圧粉体を作製した. これを，以下 $\mathrm{N}-460, \mathrm{~N}-230$ と略記する. また, SPS 用に $\mathrm{CuO}(15 \mathrm{at} \%), \mathrm{Cu}_{2} \mathrm{O}(85 \mathrm{at} \%)$, および板状 $\mathrm{Al}_{2} \mathrm{O}_{3}$ を節 2.1 と同様の手順で混合し, 圧力 $460 \mathrm{MPa}$ で多段プレス成形した圧粉体を作製した.これを, 以下 $\mathrm{GC} 2-460$ と略記する. 無配向サンプルとして, $\mathrm{CuO}(15 \mathrm{at} \%), \mathrm{Cu}_{2} \mathrm{O}(85 \mathrm{at} \%)$, および粒状 $\mathrm{Al}_{2} \mathrm{O}_{3}$ から同様の手 順により圧粉体を作製した。これを以下 N2-460 と略記する.

\section{3 焼結体の作製}

作製した圧粉体を電気炉で大気雾囲気にて温度 $1373 \mathrm{~K}$ で $0.5 \mathrm{~h}$ 保持し，焼結体を作製した．これらの焼結体は， 以下 S-GC-460, S-GC-230, S-N-460，S-N-230 と略記する.また，これまでの研究から，放電プラズマ焼結法(SPS 法)による焼結に伴って, 特定の結晶軸が水平方向の配向性を持つ実験結果が得られている，最も高密度である GC2-460 を, 圧力 5 および 40MPa で, N2-460 を圧力 40MPa でSPS 法にて焼結体を作製した. これを以下 SPS-5, SPS-40, SPS-N-40 と略記する. 焼結条件は, 圧粉体を $\phi 40 \mathrm{~mm}$ のグラファイト型にセットして圧力 5 および $40.0 \mathrm{MPa}$, 昇温速度を室温〜 $973 \mathrm{~K}$ で $100 \mathrm{~K} / \mathrm{min}, 973 \mathrm{~K} \sim 1173 \mathrm{~K}$ で $50 \mathrm{~K} / \mathrm{min}, 1173 \mathrm{~K} \sim 1273 \mathrm{~K}$ で $25 \mathrm{~K} / \mathrm{min}$ とし, 焼結温度 $1273 \mathrm{~K}$ で $10 \mathrm{~min}$ 保持した.

\section{4 配向性の解析と熱電測定}

作製した圧粉体，焼結体について，XRD による配向性の解析を行った．XRD 回折パターンから，集合組織の

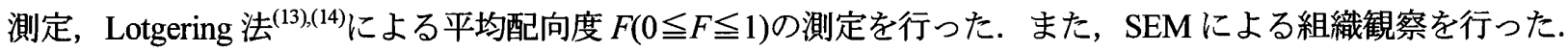

熱電特性の測定に用いる試料は, 各焼結体から長さ $40 \mathrm{~mm}$, 幅 $5 \mathrm{~mm}$, 厚さ $2 \mathrm{~mm}$ の短冊状に採取した. 大気中 にて 923K までのゼーベック係数 $S$, 電気抵抗率 $\rho$ を測定し, 式(1)より出力因子 $P\left[\mathrm{~W} / \mathrm{mK}^{-2}\right]$ を算出した.

$$
P=S^{2} / \rho
$$

\subsection{Hall 効果測定}

作製した試料について van der Pauw 法を用いて，室温におけるキャリア密度および移動度の測定を行った．長 さ $10 \mathrm{~mm}$, 幅 $10 \mathrm{~mm}$, 厚さ $1 \mathrm{~mm}$ の正方形状試験片の四隅を電極とし, 厚さ方向に磁束密度 $1 \mathrm{~T}$ の磁場を印加し, 4

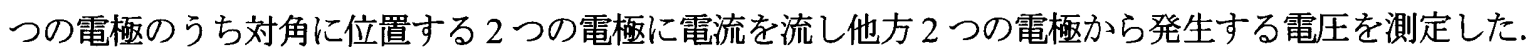

\section{3. 結果および考察}

\section{1 四向性}

作製した圧粉体の XRD 回折パターンから配向度を算出した結果, GC-460 の配向度は $F=0.21, \mathrm{GC}-230$ の配向度は $F=0.15$ となった. したがって, 配向性を有する圧粉体が作製できた. 
Fig.1 に焼結体の XRD 回折パターンを示す. $\mathrm{CuAlO}_{2}$ の電気抵抗率は, 焼結体の板面が $\mathrm{CuAlO}_{2}$ 結晶面の $\mathrm{c}$ 軸と垂直 であれば軽減できる. (0 0 3), (0 0 6 6), および(0 0 9)面のピークが強〈現れ, 配向度は最大で SPS-40 が $F=0.40$ となった. また, 配向処理していない SPS-N-40 でも配向度は $F=0.16$ となっており SPS の焼結効果によるものと考えられる. 配向性 を有する $\mathrm{CuAlO}_{2}$ 焼結体が作製できたと言える.

また, 焼結体断面の SEM像からは板状に生成した $\mathrm{CuAlO}_{2}$ が見られ，これが焼結体の配向性に関係すると考えられる. Table 1 に作製した焼結体の平均配向度 $F$ およびかさ密度をまとめる. SPS で焼結したことで, SPS-40 および SPS-N-40

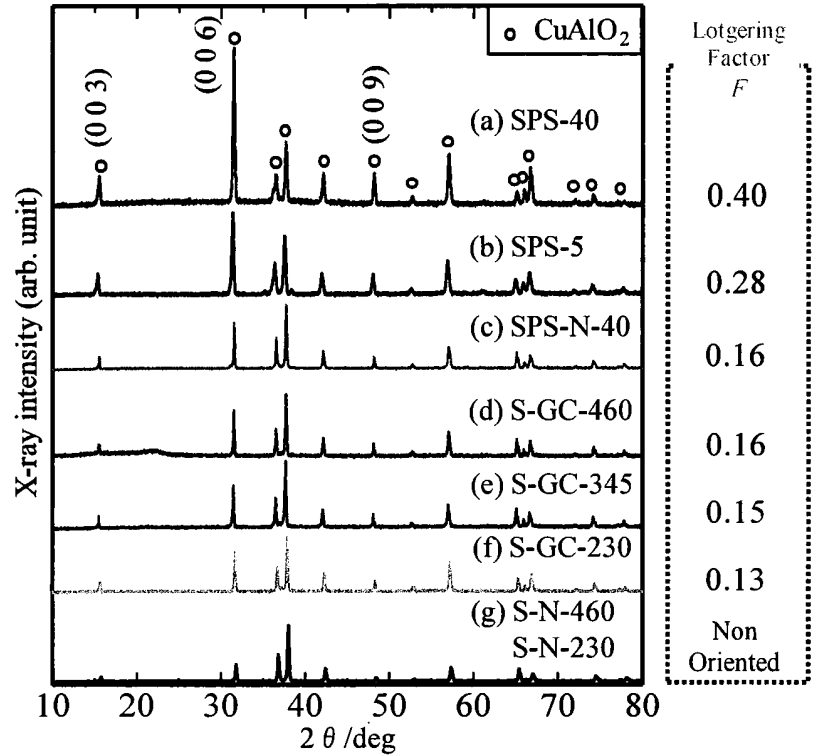

Fig.1 X-ray diffraction patterns of the sintered compacts. が非常に高密度であり, SPS-40 は配向性·密度が共 に最も高水準である.

Table1 Bulk density and orientation degree of the sintered $\mathrm{CuAlO}_{2}$.

\begin{tabular}{|c|c|c|}
\hline Sample & $F$ & $\rho\left[\mathrm{g} / \mathrm{cm}^{3}\right]$ \\
\hline SPS-40 & 0.40 & 4.93 \\
\hline SPS-5 & 0.28 & 4.19 \\
\hline SPS-N-40 & 0.16 & 5.01 \\
\hline S-GC-460 & 0.16 & 2.59 \\
\hline S-GC-345 & 0.15 & 2.53 \\
\hline S-GC-230 & 0.13 & 2.36 \\
\hline S-N-460 & & 2.78 \\
\hline S-N-230 & & 2.24 \\
\hline
\end{tabular}

\section{2 焦的特性の唡洒}

Fig.2 に作製した焼結体の電気抵抗率 $\rho, F i g .3$ にゼーベック係数 $S$, また Fig.4 に出力因子 $P$ をそれぞれ示す.これま での研究結果 ${ }^{(9),(15)}$ に比べ, 各測定温度において SPS-40 の電気抵抗率は約 96\%低減できた. しかし, SPS-5 より配向度 の低い SPS-N-40 の方が電気抵抗率が低くなっており, 密度が影響したと考えられる. ゼーベック係数は, これまでの研 究結果 ${ }^{(9),(15)}$ に比べ電気抵抗率が大幅に低下した SPS-40 に関しては大きく低下すると推察されたが, その低下は限定的 であった. その結果, SPS-40 の出力因子は大きく向上しており， $923 \mathrm{~K}$ で最大 $5.56 \times 10^{-5}\left[\mathrm{~W} / \mathrm{mK}^{2}\right]$ となった. これらの結 果から, 配向処理によって $\mathrm{CuAlO}_{2}$ 熱電材料の電気抵抗率を低減し, 高性能化が実現できた. SPS-40が, 電気伝導率, 出力因子が高くなったことは, 配向性·密度が共に最も高いためである.

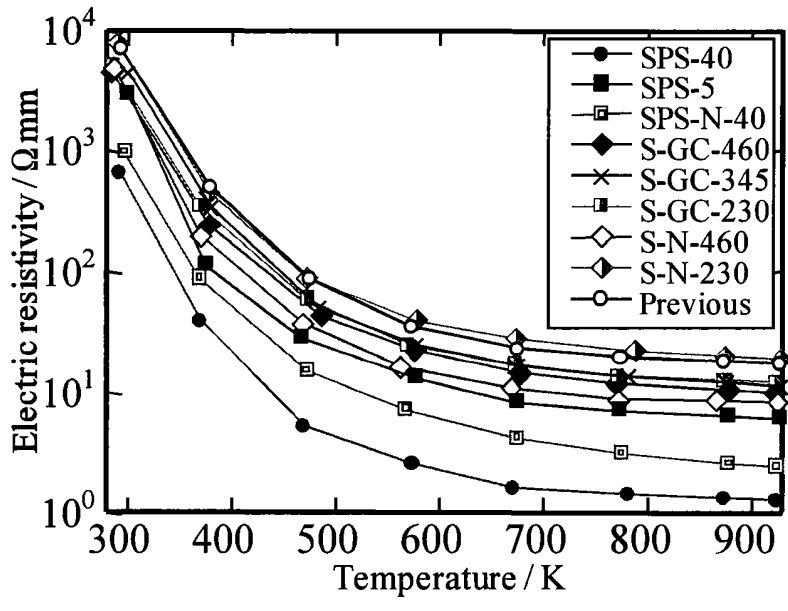

Fig.2 Temperature dependence of electric resistivity.

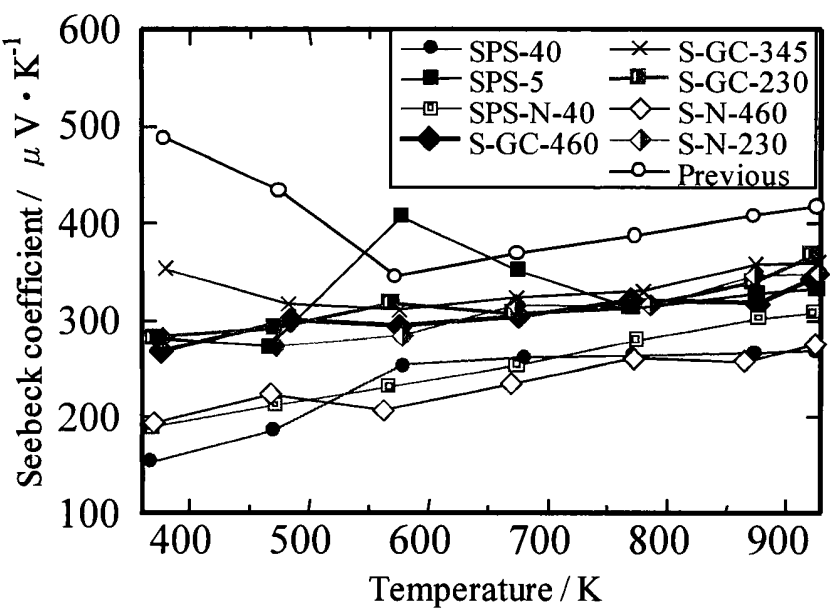

Fig.3 Temperature dependence of Seebeck coefficient. 


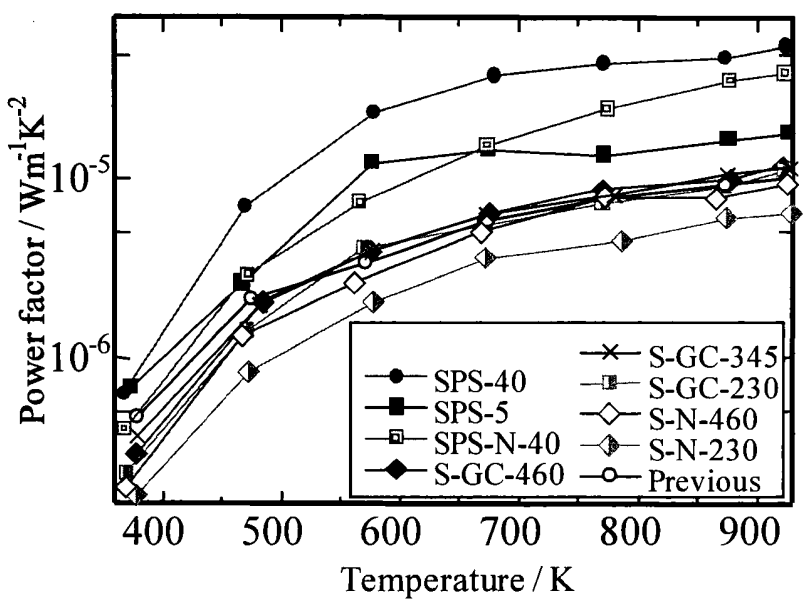

Fig.4 Temperature dependence of power factor.

\section{3 キャリア密度と移的度}

Fig.5 は作製した焼結体の Hall 効果測定によるキャリア 密度および移動度を合わせて示したものである. キャリア 密度については, 配向性・密度が高く電気抵抗率の低い 試料ほど高くなる傾向を示した. これにより, ゼーベック係 数の低下の原因がキャリア密度の上昇によるものと裹付 けることができた. キャリア移動度についても同様に配向 性·密度が増えるにつれ向上する傾向を示した.これは, 高密度化により空孔率が減少し, 空孔欠陥による散乱が 抑制されキャリア移動度が向上したと考えられる. キャリア 密度および移動度が共に向上したことによって, SPS-40 および SPS-N-40 の電気抵抗率が大きく低減したことが明 らかとなった。

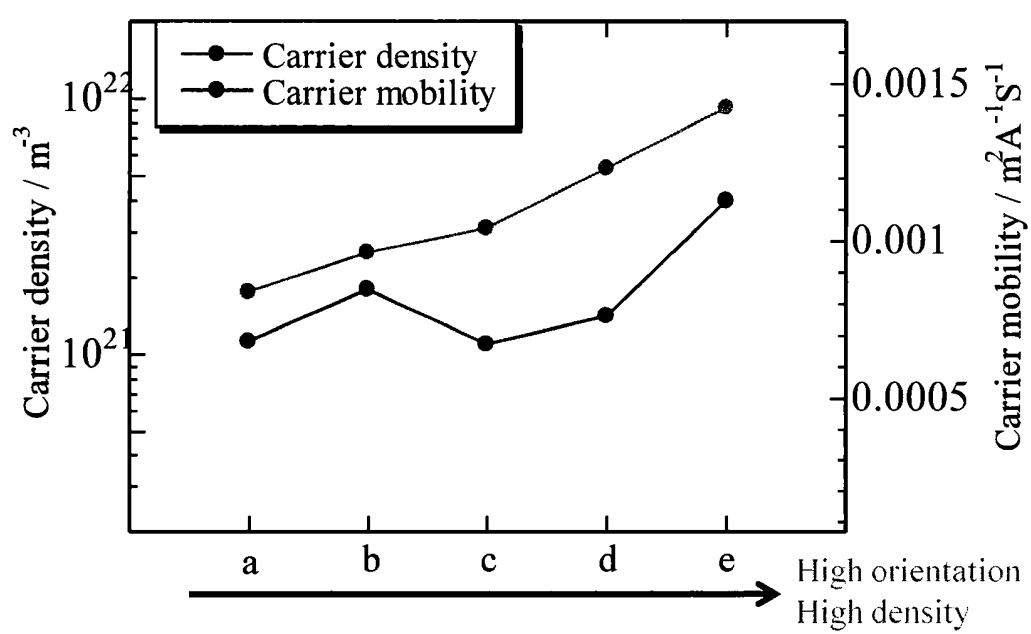

Fig. 5 Transport properties of the sintered $\mathrm{CuAlO}_{2}$.

(a)S-GC-230,(b)S-GC-345,(c)S-GC-460,

(d)SPS-N-460 and (e)SPS-40

\section{4. 結}

（1）多段プレス成形による $\mathrm{CuO}$ 粉末 $\left(\mathrm{Cu}_{2} \mathrm{O}\right.$ 粉末 $)$ および板状 $\mathrm{Al}_{2} \mathrm{O}_{3}$ 粉末の混合 粉末から配向性を有する圧粉体を作製す るプロセス，また，反応性テンプレート 粒成長法による配向性を有する $\mathrm{CuAlO}_{2}$ 焼 結体の作製プロセスを確立した.

（2）配向処理によって $\mathrm{CuAlO}_{2}$ 熱電材料 の電気抵抗率を低減し, 高性能化を実現 した. SPS-40 の電気抵抗率はこれまでの 研究と比べ 96\%低減し, 出力因子は $923 \mathrm{~K}$ で $5.56 \times 10^{-5}\left[\mathrm{~W} / \mathrm{mK}^{2}\right]$ となり,これまでの研究 結果の約 6 倍に達した.

(3) Hall 効果測定から, 配向処理および

SPS による電気抵抗率の低減はキャリア密度およびキャリア移動度の向上が大きく影響することを明らかにした. また, $\mathrm{CuAlO}_{2}$ 熱電材料のゼーベック倸数低下の原因がキャリア密度の上昇であることが示唆されている.

\section{文献}

(1) H. Kawazoe, M. Yasukawa, H. Hyodo, M. Kurita, H. Yanagi and H. Hosono, "P-type electrical conduction in transparent thin films of CuAlO ${ }_{2}$, Nature, vol. 389, No. 6654 (1997), pp. 939-942.

(2) M.S. Lee, T.Y. Kim and D. Kim, " Anisotropic electrical conductivity of delafossite-type $\mathrm{CuAlO}_{2}$ laminar crystal ", Appl. Phys. Lett., Vol.79, No.13(2001), 2028.

(3) T. Koyanagi, H. Harima, A. Yanase and H. Katayama Yoshida, "Materials Design of p-type Transparent Conducting Oxides of Delafossite $\mathrm{CuAlO}_{2}$ by Super-cell FLAPW Method", J. Phys. Chem. Solid., Vol.64 (2003), pp.1443-1446.

(4) K. Park, K. Y. Ko, and W.S. Seo, "Thermoelectric properties of CuAlO2", J. Electrochen. Soi., Vol.25(2005), pp.2219-2222.

(5) K. Koumoto, H. Koduka and W. S. Seo, "Thermoelectric properties of single crystal $\mathrm{CuAlO}_{2}$ with a layered structure", J. Mater. Chem., Vol.11(2001), pp.251-252. 
(6) A.N. Banerjee, R. Maity and K.K. Chattopadhyay, " Preparation of p-type transparent conducting CuAlO2 thin films by reactive DC sputtering "Mater. Lett., Vol.58, No.1-2(2004), pp.10-13.

（7）魯 云, 広橋光治，松尾卓哉，馬場哲治，日本材料学会第 53 期学術講演会講演論文集，2004, pp.439-440.

（8）魯 云, 広橋光治，松尾卓哉。馬場哲治，小田拓治，日本熱電学会第 1 回学術講演会論文集，2004，pp.68-69.

(9) 魯 云, 前田一成, Ying-rong Jin, 広橋光治, " $\mathrm{CuAlO}_{2}$ 熱電材料の作製における固相反応挙動とその高性能 化", 材料の科学と工学, Vol.48, No.6(2011), P. 302-307.

(10) Yun Lu, Kazunari Maeda, Katsuhiro Sagara, Liang Hao and Yingrong Jin, " Improvement of Thermoelectric Properties of $\mathrm{CuAlO}_{2}$ by Excess Oxygen Doping in Annealing", Materials Science Forum, Vol.750(2013), pp.134-137.

(11) Toshihiko Tani, "Texture Engineering of Electronic Ceramics by the Reactive-Templated Grain Growth Method", J. Ceramic, Vol.114, No.5(2006), pp.363-370.

（12）板原浩, 谷俊彦, RTGG 法で作製した結晶配向熱電酸化物セラミックス, R\&D Review of Toyota RDL, Vol.39, No.1, pp.63.

(13) Lotgering F.K., "Topotactical reactions with ferrimagnetic oxides having hexagonal crystal structures-I", J.Inorg. Nucl.Chem. Vol.9, No.2 (1959), pp.113-123

（14）田中諭，植松敬三，精密配向多結晶六方晶酸化亜鉛焼結体の製造方法，特開 2006-264316

(15) Yun Lu, Kazunari Maeda, Katsuhiro Sagara, Liang Hao and Yingrong Jin, " Improvement of Thermoelectric Properties of $\mathrm{CuAlO}_{2}$ by Excess Oxygen Doping in Annealing", Materials Science Forum, Vol.750(2013), pp.134-137. 